\title{
PERAN BATATA (Ipomea batatas L) TERHADAP PENYEMBUHAN LUKA BAKAR
}

\author{
${ }^{1}$ Channesya Sampetoding \\ ${ }^{2}$ Taufiq F. Pasiak \\ ${ }^{2}$ George Tanudjaja
}

\author{
${ }^{1}$ Kandidat Skripsi Fakultas Kedokteran Universitas Sam Ratulangi Manado \\ ${ }^{2}$ Bagian Anatomi-Histologi Fakultas Kedokteran Universitas Sam Ratulangi Manado \\ Email: csampetoding11_231@yahoo.com
}

\begin{abstract}
Theoretically, batata, Ipomea batata L (Lam) theoritically can be used in wound healing since it acts as antiseptic, antibiotic, and anti-inflammatory agents. Batata ingredients can also stimulate epithelialization in wound bed. This study aimed to obtain the role of batata juice in burn wound healing noticed from the inflammatory response aspect. This was an experimental study conducted in the research laboratory of Faculty of Medicine Univeristy of Sam Ratulangi. Samples were six rabbits divided into 2 groups: treatment group with batata juice, and control group without treatment. The histological examination showed that the quality of inflammatory tissue of the treatment group was denser, settled, and associated with edema expansion compared to the control group with diminished inflammatory components, edema, and vasodilatation, meanwhile, there were angiogenesis, improvement of dermis, and regrowth of epidermis. Conclusion: Batata juice was not superior in healing burns than the natural responses.
\end{abstract}

Keywords: batata (Ipomeas batata L), burns, skin, inflammation, wound healing

\begin{abstract}
Abstrak: Batata, Ipomea batata L (Lam) secara teoritik berfaedah untuk penyembuhan luka, yang bekerja sebagai antiseptik, antibiotik, dan anti inflamatorik. Batata berkhasiat dalam penyembuhan luka karena kandungannya yang secara bermakna merangsang pembentukan epitel jaringan luka. Penelitian ini bertujuan untuk mendapatkan peran batata terhadap penyembuhan luka bakar dilihat dari kualitas komponen radang pada jaringan luka. Sampel terdiri dari 6 ekor kelinci yang dibagi atas 2 kelompok: kelompok perlakuan dan kontrol. Kelompok perlakuan diberi jus batata pada luka bakar sedangkan kelompok kontrol tanpa perlakuan. Penelitian ini dilakukan di Laboratorium Riset Fakultas Kedokteran Universitas Sam Ratulangi dengan menggunakan metode eksperimental. Hasil identifikasi mikroskopik menunjukkan bahwa pada kelompok perlakuan kualitas komponen radang jaringan luka bakar lebih padat dan menetap disertai perluasan sembab kolagen dibandingkan kelompok kontrol dimana komponen radang dan sembab berkurang, dilatasi pembuluh darah berkurang, pertumbuhan kapiler baru, jaringan dermis yang membaik, dan epidermis yang mulai tumbuh kembali. Simpulan: Jus batata tidak memperlihatkan penyembuhan luka bakar yang lebih baik dibandingkan dengan penyembuhan luka oleh tubuh sendiri.
\end{abstract}

Kata kunci: batata (Ipomeas batata L), luka bakar, kulit, radang, penyembuhan luka

Batata, Ipomea Batatas L (Lam) berasal dari familia Convolvulaceae termasuk dalam 6 bahan pangan besar dunia yang tumbuh di daerah tropik, subtropik, dan daerah yang bertemperatur hangat. Batata dikonsumsi dengan cara direbus, digoreng, dan dikukus. Warna kulit batata sangat bervariasi, bisa berwarna merah, ungu, coklat dan putih dengan warna daging buah yang bervariasi juga, seperti putih, kuning, jingga dan ungu. Batata juga banyak digunakan sebagai obat traditional untuk 
menyembuhkan banyak penyakit. Penggunaan batata berfaedah untuk penyembuhan luka, yang bekerja sebagai antiseptik, antibiotik dan mempunyai sifat seperti kortikosteroid (anti inflamatorik). Batata dapat digunakan sebagai terapi hormonal untuk gangguan haid dan osteoporosis karena kandungannya yang dapat dimetabolisme sebagai estrogen. Dari penelitian, batata memiliki keampuhan sebagai anti-ulkus dan penyembuhan ulkus. Batata berkhasiat dalam penyembuhan luka karena kandungannya dapat secara bermakna merangsang pembentukan epitel pada luka insisi namun, batata juga mempunyai efek samping yang berpotensi menimbulkan infeksi bakterial, perdarahaan, dermatitis kontak dan perlambatan dalam penyembuhan luka. Umbi dan kulit dan Batata sangat tinggi akan polipenol, seperti antosianin, asam fenolik dan merupakan sumber yang baik dari vitamin A, B, dan C, besi, kalsium dan fosfor. Kandungan antioksidan seperti beta karoten, antosianin, kafeoildausik dan devirat asam kafeoilkuinik dapat memberikan hasil yang baik untuk penyembuhan luka. ${ }^{1-3}$

Luka merupakan suatu kejadian yang tidak dapat dihindari dalam kehidupan. Luka adalah hilang atau terputusnya kontinuitas jaringan atau kulit, mukosa membran dan tulang, atau organ tubuh lain. luka dapat disebabkan oleh aktivitas fisik, bahan kimia atau agen mikrobakteri dan penyembuhan luka merupakan salah satu dari masalah kesehatan pada umumnya. ${ }^{26}$

Penyembuhan luka merupakan proses perbaikan kulit dan jaringan lainnya. Pada saat terjadinya luka, akan terjadi respon peradangan dan sel-sel yang terlibat pada dermis akan meningkatkan produksi dari kolagen dan akhirnya jaringan epitel akan beregenerasi. Ada tiga fase dalam penyembuhan luka yaitu, fase radang, fase proliferatif dan fase remodeling. Fase peradangan dimulai tepat setelah luka terjadi dengan vasokonstriksi dan pelepasan mediator peradangan. Pada fase proliferatif terjadi granulasi jaringan oleh fibroblas dan angiogenesis, dan pada fase remodeling terjadi reformulasi dan improvisasi yang meningkatkan kekuatan tarikan dari komponen serat kolagen. ${ }^{1,26}$

\section{METODE PENELITIAN}

Penelitian ini merupakan penelitian eksperimental yang dilakukan di lab riset Fakultas Kedokteran Unsrat Manado. Sampel penelitian sebanyak 6 ekor kelinci, dibagi atas 2 kelompok: kelompok perlakuan dengan penmberian air jus batata pada luka bakar dan kelompok kontrol tanpa perlakuan.

Variabel bebas dalam penelitian ini ialah pemberian air jus batata dan variabel terikat ialah gambaran histologik luka bakar yang diberi air jus batata 2 kali sehari (jam 11.00 dan 17.00) sebanyak $5 \mathrm{ml}$ selama 7 hari berturut-turut. Gambaran histologik yang diamati antara lain kerusakan epitel, terbentuknya vesikula, komponen radang, kontraksi luka, angiogenesis, edema, dan nekrosis jaringan.

\section{HASIL PENENLITIAN \\ Hari ke 0}

Jaringan diambil pada hari pertama penelitian dilakukan sesaat setelah luka bakar dibuat. Pada sediaan H-0 ditemukan: pada kedua tepi sediaan terdapat sedikit epidermis dengan vesikel-vesikel jaringan yang edema, pembuluh berdilatasi dan bendungan. Pada bagian tengah, epidermis hilang tersisa jaringan ikat dengan banyak folikel-folikel rambut. Infiltrasi radang tidak ditemukan. Gambaran ini sesuai dengan gambaran luka bakar derajat 2b (luka bakar sampai mengenai dermis) (Gambar 1 dan 2).

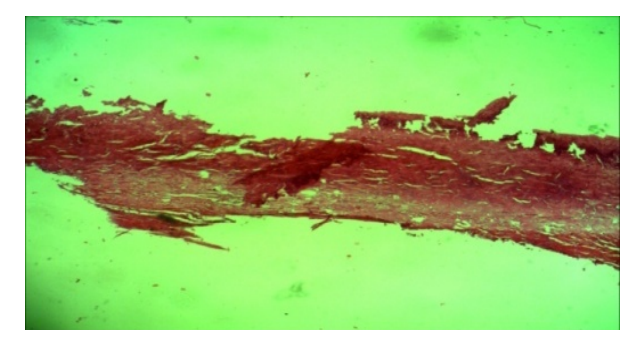

Gambar 1. Foto jaringan luka bakar H-0 pembesaran $4 \mathrm{x}$ 


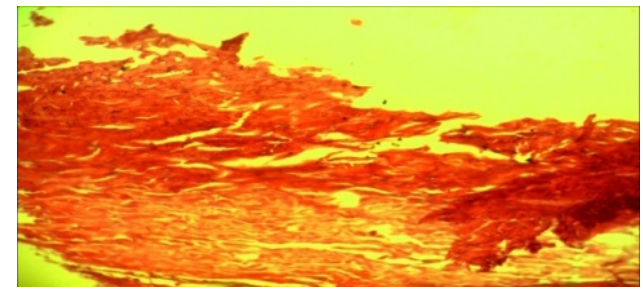

Gambar 2. Foto jaringan luka bakar H-0 pembesaran 10x

\section{Hari ke 3}

\section{Kelompok kontrol}

Pada sediaan $\mathrm{H}-3$ tanpa perlakuan atau kontrol tidak ditemukan lapisan epidermis. Terdapat jaringan ikat kolagen dan jaringan ikat regang yang sembab. Pembuluh darah berdilatasi dan bendungan. Komponen radang sedikit (Gambar 3 dan 4).

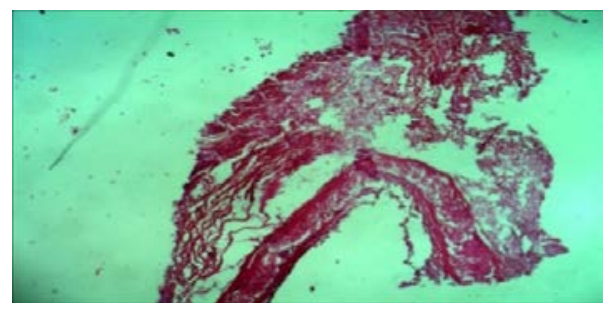

Gambar 3. Foto jaringan luka bakar $\mathrm{H}-3$ pembesaran $4 \mathrm{x}$

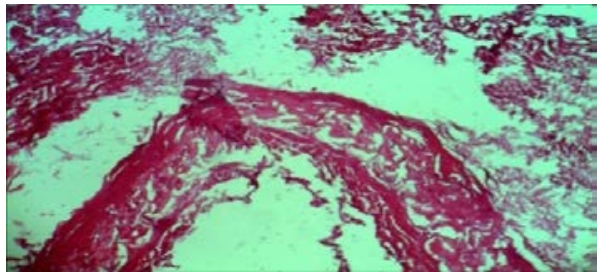

Gambar 4. Foto jaringan luka bakar H-3 pembesaran $10 \mathrm{x}$

\section{Hari ke 3 \\ Kelompok perlakuan}

Pada kedua tepi masih ditemukan epidermis dengan vesikel. Pada jaringan subdermis terdapat pembuluh darah yang berdilatasi, sembab serta infiltrasi ringan sel radang. Pada bagian tengah ditemukan epidermis hilang ditutupi oleh bekuan darah dan fibrin, sel-sel radang padat dengan nekrosis. Di bawahnya ditemukan jaringan ikat kolagen regang dengan pembuluh darah berdilatasi, bendungan, serta sembab (Gambar 5 dan 6).

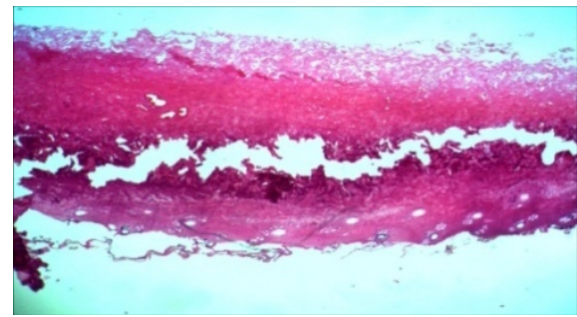

Gambar 5. Foto jaringan luka bakar H-3 pembesaran $4 \mathrm{x}$

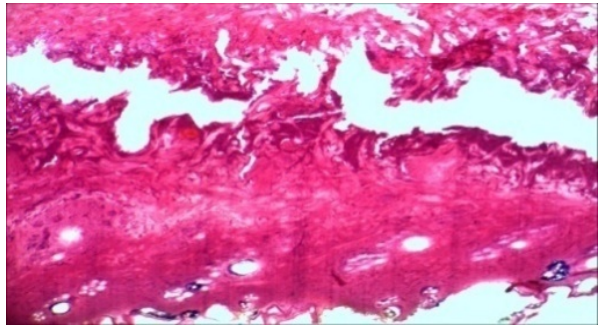

Gambar 6. Foto jaringan luka bakar H-3 pembesaran $10 \mathrm{x}$

\section{Hari ke 5}

Kelompok kontrol

Pada kedua tepi masih ditemukan epidermis, dengan vesikula-vesikula. Pada jaringan sub dermis, pembuluh darah berdilatasi disertai dengan sembab. Infitrasi radang ringan. Pada bagian tengah epidermis, ditemukan lapisan fibrin dan infitrasi sel radang ringan. Di bagian bawah, ditemukan jaringan kolagen dan beberapa folikel rambut (Gambar 7 dan 8).

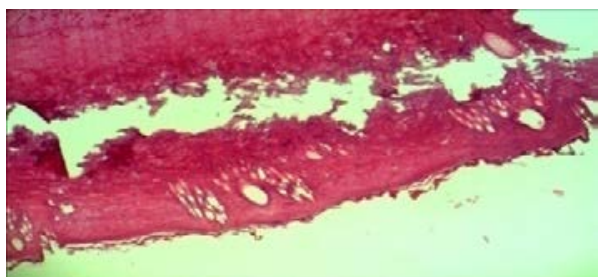

Gambar 7. Foto jaringan luka bakar H-5 pembesaran $4 \mathrm{x}$

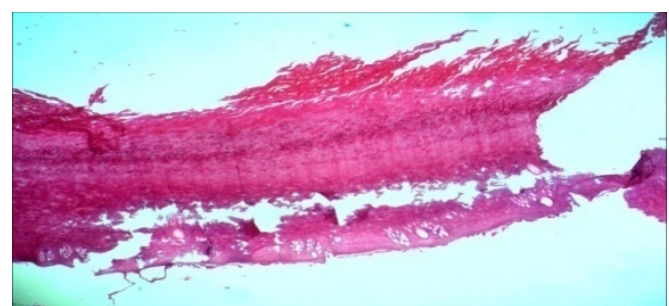

Gambar 8. Foto jaringan luka bakar H-5 pembesaran $10 \mathrm{x}$ 


\section{Kelompok perlakuan}

Pada sediaan ini ditemukan lapisan permukaan tanpa epidermis yang tersusun dari bekuan darah, fibrin dan infiltrasi selsel radang yang banyak. Di bawahnya ditemukan jaringan ikat kolagen yang agak regang dengan sejumlah pembuluh darah yang berdilatasi, bendungan, sembab dan beberapa folikel rambut dan perdarahan, serta nekrosis (Kelompok 9 dan 10).

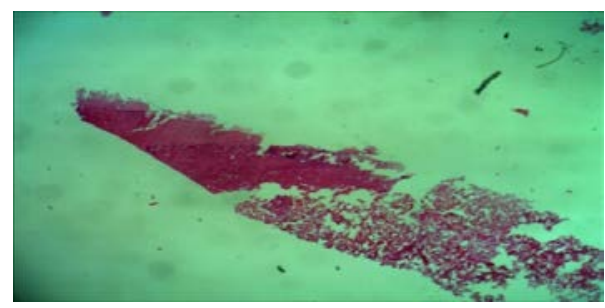

Gambar 9. Foto jaringan luka bakar H-5 pembesaran $4 \mathrm{x}$

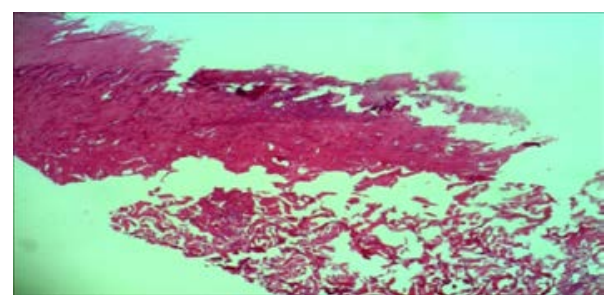

Gambar 10. Foto jaringan luka bakar $\mathrm{H}-5$ pembesaran $10 \mathrm{x}$

\section{Hari ke 7}

\section{Kelompok kontrol}

Pada bagian tepi ditemukan epidermis dengan vesikel-vesikel yang lebih kecil, pembuluh darah masih berdilatasi, bendungan serta sembab. Dibawahnya ditemukan jaringan sub epidermis dengan folikel rambut. Pada bagian tengah ditemukan bagian tanpa epidermis dengan bakuan darah dan fibrin dengan infiltrasi radang ringan. Di bawahnya ditemukan jaringan ikat kolagen regang dengan folikel-folikel rambut yang meningkat, pembuluh darah masih berdilatasi, bendungan dan sembab dengan infitrasi sel radang ringan (Kelompok 11 dan 12).

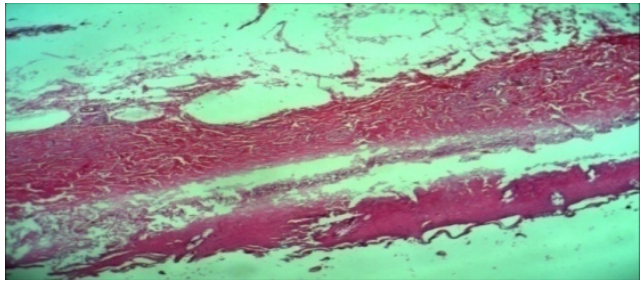

Gambar 11. Foto jaringan luka bakar H-7 pembesaran $4 \mathrm{x}$

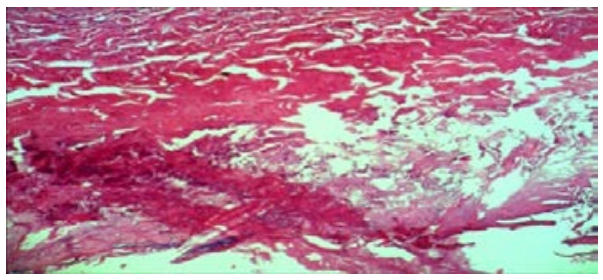

Gambar 12. Foto jaringan luka bakar H-7.1 pembesaran $10 \mathrm{x}$

\section{Kelompok perlakuan}

Pada kedua tepi ditemukan jaringan epidermis dengan sejumlah vesikel-vesikel kecil. Lapisan bawahnya ditemukan jaringan ikat kolagen dan folikel-folikel rambut. Pada bagian tengah tidak ditemukan epidermis, tersusun dari bekun darah dan fibrin dan sejumlah sel-sel radang. Di bawahnya ditemukan jaringan ikat kolagen regang, dengan beberapa folikel rambut dan di bawahnya ditemukan jaringan otot bercorak.

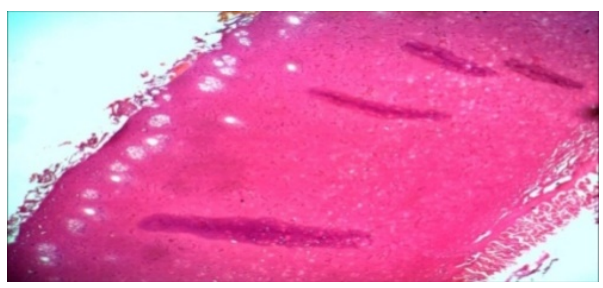

Gambar 13. Foto jaringan luka bakar H-7 pembesaran $4 \mathrm{x}$

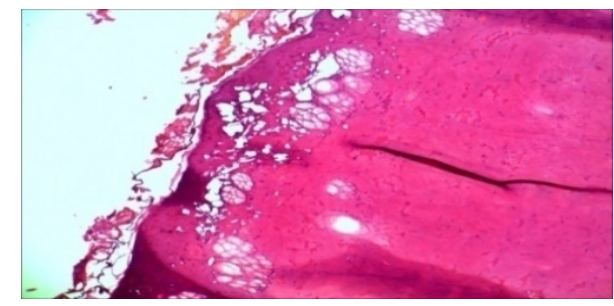

Gambar 14. Foto jaringan luka bakar H-7 pembesaran $10 \mathrm{x}$ 


\section{BAHASAN}

Berdasarkan hasil gambaran histologik ternyata kualitas penyembuhan luka bakar kelompok kontrol jauh lebih baik dibandingkan penyembuhan luka bakar dengan air jus batata. Pada $\mathrm{H}-0$, semua hewan coba dibuat luka bakar di daerah punggung sebanyak dua buah, kiri dan kanan yang sesuai dengan luka bakar derajat 2b. Hal ini dibuktikan dengan hasil gambaran histologik dari jaringan luka bakar H-0 dimana seluruh bagian epidermis dari kulit telah hilang karena cedera meninggalkan daerah dermis atau mengenai sedikit bagian dermis, belum ditemukan infiltrasi sel radang pada daerah luka, banyak vesikel sepanjang tepi luka dan pembuluh darah berdilatasi.

Parameter penilaian penyembuhan luka bakar ini berdasarkan landasan teoritik penyembuhan luka dimana terdapat 3 mekanisme yang berperan, yaitu: kontraksi luka yakni reduksi ukuran luka yang diperantarai oleh miofibroblas, regenerasi, dan repair dimana luka diganti dengan jaringan parut. Penyembuhan luka sendiri berjalan melalui 2 cara, yaitu: penyembuhan primer dan penyembuhan sekunder. Pada penelitian ini penyembuhan luka berjalan secara sekunder kerana kerusakan jaringan yang luas (luka berukuran $3 \mathrm{cmx} 3 \mathrm{~cm}$ ) dan sifat luka bakar sendiri.

Penyembuhan luka juga dipengaruhi oleh faktor sistemik, faktor lokal dan faktor inhibisi pertumbuhan. Faktor inhibisi yang menyebabkan penundaan penyembuhan baik luka akut maupun luka kronik dapat memberikan masalah klinis dan bermakna secara sistemik walaupun bersifat faktor lokal. Faktor lokal yang berpengaruh pada penelitian ini ialah benda asing yang masuk secara tidak sengaja pada air batata saat pembuatan maupun perlakuan kepada hewan coba serta faktor pembuluh darah yang terhambat oleh trombus yang timbul akibat luka bakar sehingga pasokan pembuluh darah untuk pemulihan jaringan tidak berjalan dengan baik. ${ }^{24}$

Hasil perlakuan pada hewan coba dan pemeriksaan histologik berdasarkan perbandingan tiap hari. Pada kelompok kontrol H-3 tidak terdapat lapisan epidermis. Ditemukan jaringan ikat kolagen dan jaringan ikat regang yang sembab, pembuluh darah berdilatasi dan terdapat bendungan. Komponen radang sedikit. Pada H-5 ditemukan epidermis dengan vesikula-vesikula. Pada jaringan subdermis, pembuluh darah berdilatasi disertai dengan sembab dan infitrasi radang ringan. Pada bagian tengah epidermis ditemukan lapisan fibrin dan infitrasi sel radang ringan. Di bagian bawah ditemukan jaringan kolagen dan beberapa folikel rambut. Pada H-7 ditemukan epidermis dengan vesikelvesikel yang lebih kecil, pembuluh darah masih berdilatasi, adanya bendungan serta sembab. Di bawahnya ditemukan jaringan subepidermis dengan folikel rambut. Pada bagian tengah ditemukan bagian tanpa epidermis dengan bekuan darah dan fibrin disertai infiltrasi radang ringan. Di bawahnya ditemukan jaringan ikat kolagen regang dengan folikel-folikel rambut yang meningkat, pembuluh darah masih berdilatasi, bendungan dan sembab dengan infitrasi sel radang ringan.

Pada kelompok perlakuan H-3 ditemukan epidermis dengan vesikelvesikel, juga jaringan sub dermis dengan pembuluh darah yang berdilatasi dan sembab serta infiltrasi ringan dari sel radang. Pada bagian tengah ditemukan epidermis hilang ditutupi oleh bekuan darah dan fibrin, sel-sel radang padat dengan nekrosis. Di bawahnya ditemukan jaringan ikat kolagen regang dengan pembuluh darah berdilatasi dan bendungan disertai sembab. Pada H-5 lapisan permukaan tanpa epidermis yang tersusun dari bekuan darah, fibrin dan infiltrasi selsel radang yang banyak. Di bawahnya ditemukan jaringan ikat kolagen yang agak regang dengan sejumlah pembuluh darah yang berdilatasi, bendungan, sembab dan beberapa folikel rambut. Pada H-7 kedua tepi ditemukan jaringan epidermis dengan sejumlah vesikel kecil. Lapisan bawahnya ditemukan jaringan ikat kolagen dan folikel-folikel rambut. Pada bagian tengah tidak ditemukan epidermis, tersusun dari 
bekun darah dan fibrin serta sejumlah selsel radang padat. Di bawahnya ditemukan jaringan ikat kolagen regang, dengan beberapa folikel rambut dan dibawahnya ditemukan jaringan otot bercorak.

\section{SIMPULAN}

Dari hasil penelitian dapat disimpulkan bahwa penyembuhan luka bakar dengan air jus batata tidak lebih superior dari pada penyembuhan alamiah oleh tubuh sendiri

\section{DAFTAR PUSTAKA}

1. Panda V, Sonkamble, Patil S. Wound healing activity of ipomea Batatas tubers (sweet potato). Functional Foods in Health and Disease. 2011;10:403-15.

2. Umadevi M, Kumar PKS, Bhowmik D, Duraivel S. Health and benefits cons of solanum tubersum. Journal of Medicinal Plant Studies. 2013;1(1):1625.

3. Panda V, Sonkamble M. Anti-ulcer activity of ipomea Batatas tubers (sweet potato). Functional Foods in Health and Disease. 2012;2(3):48-61.

4. Bakkara CJ. 2012. [Home page on internet] [cited 2014 Okt 13]. Available From http://repository.usu.ac.id/bitstream/12 3456789/31496/6/Chapter\%20II.pdf

5. Tambajong EH. Radang dan Pemulihan Jaringan, 1999. 